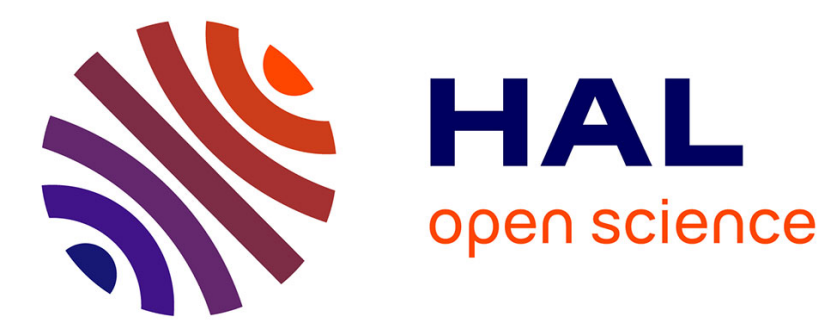

\title{
How 'Provincial' is your Region? Openness and Regional Performance in Europe
}

Alfonso Gambardella, Myriam Mariani, Salvatore Torrisi

\section{To cite this version:}

Alfonso Gambardella, Myriam Mariani, Salvatore Torrisi. How 'Provincial' is your Region? Openness and Regional Performance in Europe. Regional Studies, 2009, 43 (07), pp.935-947. 10.1080/00343400801932268 . hal-00516197

\section{HAL Id: hal-00516197 \\ https://hal.science/hal-00516197}

Submitted on 9 Sep 2010

HAL is a multi-disciplinary open access archive for the deposit and dissemination of scientific research documents, whether they are published or not. The documents may come from teaching and research institutions in France or abroad, or from public or private research centers.
L'archive ouverte pluridisciplinaire HAL, est destinée au dépôt et à la diffusion de documents scientifiques de niveau recherche, publiés ou non, émanant des établissements d'enseignement et de recherche français ou étrangers, des laboratoires publics ou privés. 


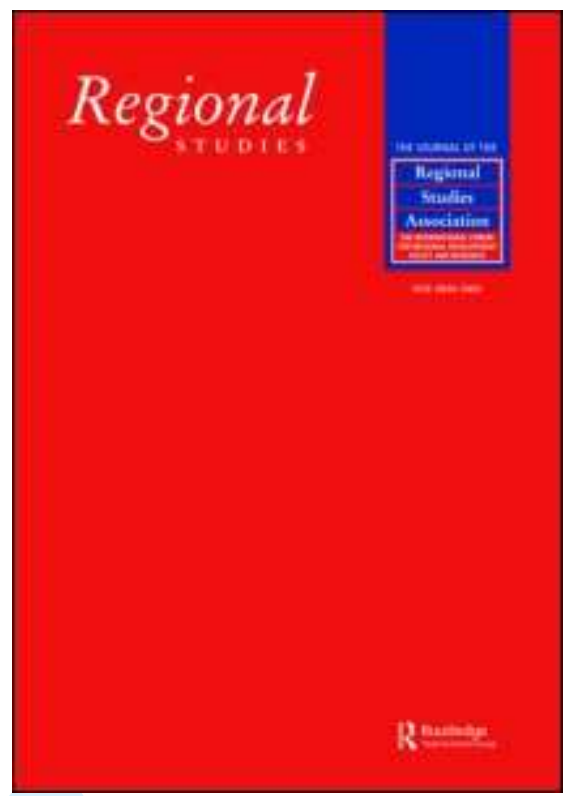

\section{How 'Provincial' is your Region? Openness and Regional Performance in Europe}

\begin{tabular}{|c|l|}
\hline Journal: & Regional Studies \\
\hline Manuscript ID: & CRES-2006-0199.R2 \\
\hline Manuscript Type: & Main Section \\
\hline JEL codes: & $\begin{array}{l}\text { O18 - Regional, Urban, and Rural Analyses < O1 - Economic } \\
\text { Development < O - Economic Development, Technological Change, } \\
\text { and Growth, O30 - General < O3 - Technological Change|Research } \\
\text { and Development < O - Economic Development, Technological } \\
\text { Change, and Growth, O47 - Measurement of Economic } \\
\text { Growth|Aggregate Productivity < O4 - Economic Growth and } \\
\text { Change, and Growth, R11 - Regional Economic Activity: Growth, } \\
\text { Development, and Changes < R1 - General Regional Economics < R } \\
\text { - Urban, Rural, and Regional Economics }\end{array}$ \\
\hline \hline Keywords: & $\begin{array}{l}\text { openness, regional performance, regional advantages, technology, } \\
\text { European regions }\end{array}$ \\
\hline \hline
\end{tabular}

\section{SCHOLARONE \\ Manuscripts}




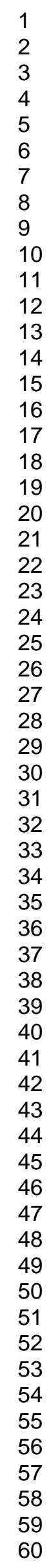 \\ Page 1 of 36}

1

2

4

5

7

8

10

11

12

14

15

16

17

19

20

22

23

25

26

27

29

30

32

33

35

36

37

39

40

41

42

44

45

46

47

48

50

51

53

54

55

57

58

59

60

http://mc.manuscriptcentral.com/cres Email: regional.studies@fm.ru.nl 


\title{
How "Provincial" is your Region? \\ Openness and Regional Performance in Europe
}

\author{
Alfonso Gambardella \\ Department of Management \& Cespri, Bocconi University \\ Via Filippetti 9, 20122, Milano, Italy \\ agambardella@unibocconi.it \\ Myriam Mariani \\ Department of Institutional Analysis and Public Management \& Cespri, \\ Bocconi University, via Sarfatti, 25, 20136, Milano, Italy \\ mmariani@unibocconi.it \\ Salvatore Torrisi \\ Department of Management, University of Bologna \\ via Capo di Lucca 34, 40126 Bologna, Italy, and Cespri, Bocconi University, via \\ Sarfatti, 25, 20136, Milano, Italy \\ torrisi@unibo.it
}

Received: August 2006

Accepted: October 2007 


\begin{abstract}
By employing 1995-2000 data on European regions we construct an index of regional openness based on the share of hotels on population and the share of population that speaks a second language. This index has an impact on regional performance after controlling for technological capabilities, agglomeration economies, and other factors. Apart from a direct effect of openness, we find an indirect effect coming through patents. This suggests that open regions tap into wider knowledge networks that then affect performance. From a policy perspective, making a region less "provincial" can be as important as investments in local infrastructures and networks.
\end{abstract}

Keywords: openness, regional performance, regional advantages, technology, European regions.

JEL classifications: O18, O30, O47, R11

\title{
CRES-2006-0199.R2
}

Dans quelle mesure votre région est-elle provinciale?

\section{Ouverture et performance régionale en Europe}




\title{
Alfonso Gambardella, Myriam Mariani et Salvatore Torrisi
}

\begin{abstract}
Nous appuyant sur des données sur les régions européennes pour la période 1995-2000, nous établissons un indice d'ouverture régionale basé sur la proportion d'hôtels par rapport à la population et sur la proportion de la population qui parle une deuxième langue. Cet indice a un impact sur les performances régionales d'après le contrôle des capacités technologiques, des économies d'agglomération et d'autres facteurs. Outre un effet d'ouverture direct, nous observons un effet indirect causé par les brevets. Cela laisse à penser que les régions ouvertes puisent dans des réseaux de connaissances beaucoup plus larges, ce qui entraîne un effet sur les performances. Dans une perspective politique, il peut être aussi important de rendre une région moins provinciale que d'investir dans des infrastructures et des réseaux locaux.
\end{abstract}

Mots-clés : ouverture, performance régionale, avantages régionaux, technologies, régions européennes.

Classement JEL : O18, O30, O47, R11

CRES-2006-0199.R2

Wie 'provinziell' ist Ihre Region? Offenheit und regionale Leistung in Europa Alfonso Gambardella, Myriam Mariani and Salvatore Torrisi

Unter Nutzung von Daten über europäische Regionen im Zeitraum von 1995 bis 2000 konstruieren wir einen Index der regionalen Offenheit anhand des Anteils von Hotels an der Bevölkerung sowie des Anteils der Bevölkerung mit Fremdsprachenkenntnissen. Dieser Index wirkt sich auf die regionale Leistung aus, wenn man auf technologische Fähigkeiten, Agglomerationswirtschaften und weitere Faktoren kontrolliert. Abgesehen von einer direkten Auswirkung der Offenheit stellen wir eine indirekte Auswirkung durch Patente fest. Dies weist darauf hin, dass sich offene Regionen breitere Wissensnetzwerke zunutze machen, welche sich ihrerseits auf die Leistung auswirken. Von der politischen Warte aus betrachtet kann es genauso wichtig sein, eine Region weniger 'provinziell' zu machen, wie es wichtig ist, in lokale Infrastrukturen und Netzwerke zu investieren.

Keywords:

Offenheit

Regionale Leistung

Regionale Vorteile

Technologie

Europäische Regionen

JEL classifications: O18, O30, O47, R11

CRES-2006-0199.R2

¿Cómo es de "provincial" tu región?

Accesibilidad y desempeño regional en Europa 
Alfonso Gambardella, Myriam Mariani and Salvatore Torrisi

Empleando datos de 1995-2000 sobre las regiones europeas, construimos un índice de accesibilidad regional basado en la proporción de hoteles en la población y la proporción de la población que habla una segunda lengua. Este índice tiene un efecto en el desempeño regional si se controlan las capacidades tecnológicas, las economías de aglomeración y otros factores. Aparte de un efecto directo de accesibilidad, observamos un efecto indirecto que procede de las patentes. Esto sugiere que las regiones abiertas aprovechan redes más amplias de conocimiento que luego afectan al desempeño. Desde una perspectiva política, puede ser tan importante conseguir que una región sea menos "provincial" como invertir en infraestructuras y redes locales.

\section{Keywords:}

Accesibilidad

Desempeño regional

Ventajas regionales

Tecnología

Regiones europeas

JEL classifications: O18, O30, O47, R11 


\section{INTRODUCTION}

Regional performance has drawn increasing attention in recent years. Its growing popularity owes a great deal to the fortunes of some regions of the world. For example, the story of Silicon Valley prompted Saxenian (1994) to dig into the determinants of "regional advantages." At the same time, regional inequalities have raised a good deal of attention, especially in Europe (CEC, 2007).

A classical explanation of regional advantages is local infrastructures and the local milieu for innovation and growth (e.g., Porter, 1998; Swann et al., 1998; Döring and Schnellenbach, 2006). Another explanation is technology. Audretsch and Feldman (1996) showed that in the US technological activities tend to cluster. Verspagen (1997) and Caniels (1999) obtained similar results for Europe. Fagerberg et al (1997) found that the R\&D-intensity of European regions positively affects their GDP growth, while Paci and Usai (2000) found that in Europe regional patents per capita are positively correlated with labor productivity.

The goal of this paper is to show that another determinant of regional advantages is their "openness," and particularly their international openness. We study empirically the extent to which openness contributes to the economic performance of the European regions. While there is an established literature on openness at the level of countries, there is not much at the regional level. This is a serious gap because there are differences across regions within a country. Apart from performance, they exhibit differences in industrial or technological activity, as well as in their attitude towards openness.

Moreover, the present literature on countries has focused on the classical tradeopenness (export plus imports as a share of GDP). But in a world in which knowledge, services, along with intangible skills, assets, or linkages have become more important, there are subtle elements of openness that are not fully captured by these classical 
measures. We then broaden the concept of openness from mere trade-openness to the ability of regions to capture external opportunities. This ability depends on the extent to which the region is connected to the external world, which in turn depends on factors such as the inward or outward mobility of people (e.g., students, human capital, workers), the presence of multinational enterprises, the familiarity of the local population with international languages or with other cultures.

Clearly, these factors also affect trade, as they may result in greater exports or imports. Yet, this is not key for us. What we are interested in is the extent to which a region is embedded in broad networks. This affects its productivity in several ways. Apart from greater exports or imports, or classical advantages from trade specialization, a region that is hooked into wider networks benefits earlier or more effectively from international knowledge spillovers or from other growth opportunities (e.g., shocks to international demand). Similarly, these networks provide exposure to knowledge, resources, learning processes, or to more advanced benchmarks or best-practices that enable the regions to produce better or more advanced goods and services, or to make more productive investments. In light of the greater importance of intangible goods, services, and knowledge in economic activities, all these factors - and the associated "soft" linkages - have become increasingly important for economic performance. Many fast-growing regions of the world today - e.g., Taiwan, Singapore, South Korea, Ireland, Israel, or the software industry in Bangalore or other Indian regions - have based their growth on patterns of international openness like the ones that we are highlighting here. Apart from exports and imports, their international connections with leading countries through knowledge channels, mobility of people, multinational firms, familiarity with the English language, have been crucial for their success (e.g., Bresnahan and Gambardella, 2004; Arora and Gambardella, 2005). 
We employ data on European NUTS (Nomenclature des Unités Territoriales Statistiques) regions from the Eurostat database REGIO. To measure regional performance we use a proxy of regional labor productivity. We divide our data into two periods: 1995-1997 and 1998-2000. Since openness changes slowly, yearly data may be too short a window, and they could boost the statistical significance of our results simply because they repeat observations over time. We then average out yearly variables over the three years.

Along with controls, we regress our measure of regional performance on measures of technological competencies, agglomeration, and openness. We measure technological competencies by the stock of patents in the region, and agglomeration factors by population density. Both are standard measures of these variables (e.g., Ciccone, 2002). To measure openness we have to deal with two issues. First, as noted, standard measures of trade-openness are not available at the regional level. Second, we seek measures that capture the ability of a region to communicate and interact outside its boundaries and to be part of international networks or learning processes, rather than just classical trade measures. We then construct an index of openness composed of an estimate of the regional population share who speaks a foreign language and the share of hotels on the population of the region.

After controlling for endogeneity we find that technological competencies, agglomeration, and openness have positive impacts on the performance of regions. In addition, we find that openness has an indirect effect on performance through technology, viz. openness boosts scientific and technological activities, which in turn affect regional economic performance.

The next section discusses our notion of openness. Section 3 presents the data, the econometric specification, and the empirical results for the regional performance 
equation. Section 4 presents our analysis and results of the two-equation model with the estimated direct and indirect effects of openness. Section 5 concludes.

\section{BENEFITS OF OPENNESS}

The existing literature on economic openness has focused on the openness of countries. To our knowledge, this paper is one of the few studies that looks at the openness of regions within countries. ${ }^{1}$ There are advantages in moving from the country to the regional level. In particular, the analysis of openness at the country-level neglects the considerable differences in both the openness and the economic performance of regions within countries. This is especially true for Europe. In the 1990s about one-fourth of the population of the European Union (EU) lived in regions whose per-capita income was lower than $75 \%$ of the EU average. In the US, only Mississippi and West Virginia, which cover $2 \%$ of the US population, have a per-capita income lower than $75 \%$ of the US average (Puga, 1999).

At the regional level there are neither systematic data on international exports and imports, nor on inward and outward flows of goods and services to other regions within the same country. Moreover, there are no data on other variables typically used by the international literature, like foreign direct investments. However, as noted, the scope of this paper is to examine the impact of a broader concept of openness. The proxies of openness that we use in our empirical analysis - viz. the familiarity with a foreign language, and the receptivity of the regions to non-resident visitors - are correlated with some basic factors associated with the openness of regions, which includes tradeopenness itself. But they are more primitive than trade-openness in the sense that they can cause trade flows along with other opportunities. Ultimately, this means that the only relevant limitation due to the lack of data on trade flows at the regional level is that we cannot estimate their effects separately from knowledge spillovers, linkages, or other 
flows of information.

Within the literature on openness at the level of countries, Frankel and Romer (1999) is a key reference. They study the effects of trade (exports plus imports over GDP) as a measure of openness on income per capita for a sample of countries worldwide, and find a positive relationship. Two features of their study are similar to the ones that we propose in this paper. First, unlike previous studies, they use instrumental variables to control for the endogeneity of trade. Second, they recognize that their measure of trade-openness may be a proxy for the many ways in which interactions between countries affect income - e.g., specialization, increasing returns associated with larger markets, mobility of people, and wider knowledge spillovers. In this respect, they also take the approach, as we do in this paper, that the advantages and sources of openness are broader than the mere export-import phenomenon. Alcalà and Ciccone (2004) is another relevant study in this context. Their approach is similar to Frankel and Romer. They find similar results at the country level after instrumenting for both trade-openness and the institutional quality of countries.

The perception that there are some basic factors that reduce trade costs, raise the openness of a country, and through that affect income in various ways, has become widely accepted. One factor that has drawn increasing attention is the knowledge of the English language. In 2001 the European Edition of Business Week (2001) argued that in European business there is an increasing divide between those who know English and those who do not. The article reports that in Continental Europe only $41 \%$ of people speak English, and only $29 \%$ speak it well enough to carry on a conversation. It also reports that, in several jobs, from factory floors to offices, workers who speak English command $25 \%$ to $35 \%$ higher salaries.

A good example of the set of factors that may reduce the cost of international openness, and give rise to corresponding benefits in terms of growth and incomes, is 
provided by Arora et al. (2004). In the 1990s the international demand for information technology (IT) services boomed in the developed countries, and particularly in the US. This has produced an IT skill shortage in these countries, to which IT producing and using firms have responded by outsourcing some of their activities to new locations. Several emerging economies were in the position to offer their services, but only a few have been able to catch the new market opportunities, particularly India, Ireland, and Israel. A critical reason was their natural exposure to international linkages in the form of language and connections with skilled emigrants, along with access to the services of foreign institutions such as multinational corporations and venture capital firms.

Unfortunately, we do not have systematic data on the movement of immigrants from and to the regions. However, our goal is to highlight more generally the benefits to an individual country or region produced by "soft" linkages with the international setting, like flows of knowledge, expertise, and communication. The cases of Indian, Irish, or Israeli immigrants in recent years exemplify these processes as these immigrants have, among other types of linkages, several knowledge and information ties with their countries of origin, and these flows of knowledge or information have shown to be important elements of their success since the 1990s.

The same can be said about multinational firms or relationships to international sources of capital. We lack systematic data on the presence of multinational firms or access to international capital at the regional level. Yet openness to multinationals or international capital enhance the opportunities of a region to take advantage of shocks that increase the ability of regional economies to benefit from knowledge by more advanced organizations, institutions, or markets. For example, many Irish software firms have benefited from spillovers associated with the presence of multinational firms in Ireland, mostly in the form of job mobility. As an illustration, DLG, a small Irish firm specialized in localization software development and testing (62 employees), has greatly 
benefited from its managing director's previous working experience with Lotus, which helped consolidate links between the two firms. The director has helped the DLG staff to absorb organizational and management best practices from Lotus. Moreover, many successful Irish software firms have started as programming houses (subcontractors) for the local subsidiaries of multinational corporations and have then exploited the network and reputation of these customers to gain access to foreign markets.

To summarize, the discussion in this Section suggests that openness per se, which includes participation in international knowledge flows, links to international networks, ability to capture opportunities that arise at the international level, or openness to the presence of multinational enterprises, can have important implications for the economic performance of a region. These implications can take the form of sources of demand, spillovers, or transfers of best practices, which go beyond the mere trade flows.

\section{REGIONAL PERFORMANCE IN EUROPE}

\subsection{Sample, data, variables, and their sources}

Our empirical analysis is based on a sample of NUTS European regions. The source of data is the Eurostat REGIO data base (2004 edition). We employed NUTS2 regions for Austria, Belgium, Finland, Germany, Greece, Ireland, Italy, the Netherlands, Portugal, Spain, and Sweden (e.g., Oberbayern, Niederbayern, Lombardy, Cataluña). For France and the UK we were forced to use NUTS1 regions (e.g., Eastern Regions instead of East Anglia or Essex) because of too many missing values for their NUTS2 regions. For the same reason we could only use data for Denmark as a whole. These cases, however, are unlikely to create any particular problem in our analysis, since we control for area and population of regions.

The dependent variable and all the covariates that we are interested in are available for 1995-2000. However, rather than using an annual panel of regions and 
years we divided our time dimension into two periods, 1995-1997 and 1998-2000, and we averaged out our variables over each three year period. As noted in the Introduction, yearly data may represent too short intervals. Changes in openness, technological capabilities, or population density occur in longer time spans. The use of annual data would be like running monthly data for classical annual panel estimation. This would boost the statistical significance of the regressors because of repeated observations of the dependent variable for each covariate. Thus, as a conservative approach we lumped the six year period in two three year periods.

The number of observations in our sample varies from 248 to 164 because of differences in missing data for our instruments. Since we use time and country dummies, and there are no reasons to believe that the missing data are systematic, we run our regressions with all the available information for that regression. However, the empirical results of this paper do not change considerably when we run our regressions on the sample common to all the specifications. Also, in spite of the missing data, the number of observations in each of the two sample periods, 1995-1997 and 1998-2000, is fairly balanced. Our dependent variable is the region GDP over the population ages between $25-65$. We interpret it as a proxy for region labor productivity. ${ }^{2}$

Table 1 lists and defines the variables employed in our analysis. Table 2 reports descriptive statistics. We employed databases other than REGIO for UNILAB95, LANG, and LANG18. To obtain UNILAB95 we downloaded information on about 21,000 research laboratories located in Europe from the European $R \& D$ database 1996 produced by Reed Elsevier Publisher. Of these, 5,271 were university laboratories for which we recorded address and zip-code in order to assign each laboratory to the region in which it was located. The variables LANG and LANG18 were obtained from the Special Survey on Languages performed in 2000 by Eurobarometer (European Opinion Research Group). This survey interviewed nearly 16,000 people in 15 European 
countries, and it provided the NUTS region of the interviewees. We computed the shares of individuals over 27 years of age in each region who speak at least one foreign language, and the share of individuals who learned it before they were 18. As we shall see, we use LANG18 as an instrument for LANG. The 27-year-old threshold enables us to construct this instrument, which we could not create if we took the share of the entire population, and to focus on individuals of working age. Since the share of individuals over 27 is computed at the beginning of our two time periods, LANG and LANG18 vary over time as well. ${ }^{3}$

\section{TABLE 1 AND 2 ABOUT HERE}

\subsection{Regional Performance: Specification}

We start by estimating the following log-linear equation:

$$
\begin{aligned}
\log \left(Y_{i t}\right)= & \text { constant }+ \text { country dummies }+ \text { time dummy }+ \\
& \alpha_{O P E N} \cdot\left[\alpha_{H O T E L} \cdot \log \left(H O T E L_{i t}\right)+\left(1-\alpha_{H O T E L}\right) \cdot \log \left(\text { LANG }_{i t}\right)\right]+ \\
& \alpha_{T E C H} \cdot \log \left(\text { TECH }_{i t}\right)+\alpha_{D E N S} \cdot \log \left(D E N S_{i t}\right)+ \\
& \alpha_{P O P} \cdot \log \left(P O P_{i t}\right)+\text { controls }+\varepsilon_{i t}
\end{aligned}
$$

where the $\alpha$ are parameters to be estimated, $\varepsilon_{i t}$ is the error-term, TECH is alternatively HRSTE or KPAT, and all the other variables are defined in Table 1.

The term in the square bracket is our index of openness. We measure openness as a combination of two factors: the share of hotels on population (HOTEL) and our language measure (LANG), which proxies for the share of the regional population that speaks a foreign language. The parameter $\alpha_{\text {HOTEL }}$ estimates the weight of HOTEL vs. LANG, while $\alpha_{O P E N}$ measures the impact of openness on regional performance.

The variable LANG is clearly correlated with the extent to which a region is linked to, communicates with, or can reach outside of its boundaries. Our discussion in 
Section 2 suggests that we may want to use the knowledge of English rather than generically of a second language. Since the Eurobarometer survey reports the specific languages known by the surveyed individuals, we constructed the English analog of LANG, i.e., the share of the population that speaks English. However, the reason why we employ LANG is because knowing English is not the right measure for British regions. At any rate, in Section 4.2 we present as a robustness check our regressions with the English equivalent of LANG and after removing the British regions from our sample. All our empirical results do not change.

We think that HOTEL, which accounts for the capability of a region to host nonresidents, provides a natural complement to LANG as a measure of openness in our framework. The variable LANG accounts for many of the factors that we discussed in Section 2. Clearly, knowledge of languages is a specific measure of the ability to communicate internationally, and in this respect it is a proxy for the extent to which the people in a region interact with the environment outside the region itself. This is partly captured by HOTEL as well, as a region with a larger number of hotels is more open to the inward and outward movement of people. To some extent, we may suggest that while LANG is more likely to be a measure of the soft international linkages widely discussed in Section 2, HOTEL may account to a greater extent for more traditional openness, like the flow of businessmen to the region. However, rather than going further in this distinction, the use of more proxies for openness spans more dimensions of the latent variable that we intend to measure.

The REGIO dataset provides other potential measures of openness like the number of airplane passengers or the annual number of non-residents spending nights in hotels or other accommodations (e.g., camping), which we tried as additional components of our index. However, they are correlated with HOTEL and LANG, add no statistical power to our estimation, and produce collinearity. Moreover, not only is an 
index using only a few indicators justified empirically by this correlation, but also theoretically, because most of the factors that account for the openness of a location are themselves correlated with each other. For example, the Asian Tigers, Ireland, Israel, or the Indian software industry show high levels of exports; they benefit from international spillovers because of their international linkages (i.e., emigrants, the use of the English language, etc.); they are open to multinational enterprises; they are part of an extensive division of labor particularly with the US (Arora et al. 2004). In sum, given our limited number of observations, HOTEL and LANG cover the most parsimonious set of proxies for our purposes.

A potential concern is that HOTEL and LANG may capture the effect of tourism on regional performance. However, at the level of NUTS1 and NUTS2 regions, tourism covers a small share of regional economic activities. A report of the Italian Ministry of Industry on the economic perspectives of tourism in Italy indicates that direct and indirect activities linked to the tourist sector account for 5\% of the Italian GDP, and for $8 \%$ of the GDP of the most tourist NUTS2 regions (Ministero dell'Industria, 2000).

Since these figures include activities that are very indirectly associated with tourism (e.g., the food industry), the effective share of relevant tourist activities can be quite smaller and their direct effect on regional GDP is largely negligible. At any rate, as listed in Table 1, we include a control for the tourist intensity of the region in our regressions, TOURISM. This is the share of annual arrivals of non-residents in the region who are accommodated in establishments other than hotels, e.g., camping or hostels, which is clearly associated with tourist activities.

Finally, both HOTEL and LANG are long-run variables. One reason for preferring HOTEL to other measures provided by REGIO, like the non-residents spending nights in the region or the number of beds available, is that these variables are more likely to be affected by short-term factors, whereas building new hotels has a 
longer gestation. Similarly, since learning a language takes months or years, the share of population that knows a second language is unlikely to be fickle in the short-run. As we shall see below, we also instrument for LANG, and then in a subsequent specification for HOTEL, to eliminate further potential endogeneity.

As far as the other covariates are concerned, we employ HRSTE or KPAT as measures of regional skills or technological capabilities. The former is broader than just patents. However, since the 1990s there has been a significant upsurge in patenting, and patent stocks increasingly reflect relevant technological outputs. Moreover, unlike HRSTE, which is an input, patents account for actual technological achievements. At the same time, HRSTE may be affected by differences in the employment levels of educated individuals across regions. By alternating the two measures we can check for potentially different effects. We also include them jointly, but their collinearity reduces their significance.

We tried several variables as controls. We employed the share of agricultural or arable land, or whether the region borders with the sea. We also introduced a covariate accounting for the level of capital formation in the region. Unfortunately, there are many missing observations for this variable in REGIO. We therefore used it along with a dummy for missing observations, and to avoid endogeneity we lagged it by three periods. In general, the effect of capital formation and that of the other controls were statistically not significant, and all the results presented below are robust to these different specifications. Only the length of motorways in the regions $\left(M T W_{i t}\right)$ was statistically significant in some specifications. To be parsimonious with the regressors, and in light of the correlation among the many potential controls, we decided to use $M T W_{i t}$ as our summary control for the characteristics of regions not accounted for by the other covariates. As noted earlier, we also included a control for the tourist intensity of the region. 
We estimated (1) by OLS and then by gradually instrumenting different potentially endogenous covariates. We first instrumented for LANG and our technology variables, HRSTE or KPAT, by using LANG18 and UNILABS95. They are the two covariates in our regressions that would most likely suffer from endogeneity.

Knowledge of a second language could be the outcome of a richer region because higher income per capita may induce greater openness and related investments. This is pretty much the reason why the literature on openness at the level of countries, and particularly Frankel and Romer (1999), instrumented for their measures of tradeopenness. Our instrument, LANG18, ignores individuals who might have learned the language because of recent shocks. Our 27-year-old threshold then ensures at least a 10 year window between the current knowledge of the language and the period in which it was learned. This makes it more likely that our language measure is a cause and not a consequence of regional performance. The need for instrumenting for HOTEL is less compelling. As with any kind of construction, hotels typically require time to be built. Hence, they could be taken as fixed in the short-run.

It is more important to instrument for the technological development of the region. Both HRSTE and KPAT are stock measures, and hence they can also be taken as exogenous in the short-run. Yet in the period that we are considering, economic development, especially in an advanced setting like Europe, had already become increasingly dependent on technology and innovation. Therefore, we need to take into account whether HRSTE or KPAT cause such processes, or if they are affected by shocks that also affect per-capita income. The stock of university labs in 1995, UNILABS95, is a more exogenous measure of the scientific and technological capabilities of the region because it is fully pre-sample. Moreover, university labs take time to be established and hence they reflect a long history of scientific or technological skills in the area. Also, since UNILABS95 only accounts for university labs, this 
measures an even more indirect contribution to regional performance than if we included industry labs as well.

Finally, we report a specification in which we employed lagged or pre-sample variables as instruments for all the covariates in (1) apart from the constant, the dummies, AREA, and TOURISM. Specifically, we employed the following instruments (see Table 1 for definitions): constant, country dummies, time dummy, $\log \left(P O P_{i t-2}\right)$, $\log \left(A R E A_{i}\right), \log \left(M T W_{i t-2}\right), \log \left(U N I L A B 95_{i}\right), \log \left(P A S S_{i t-4}\right), \log \left(L A N G 18_{i t}\right)$. Population and motorways are lagged two periods because REGIO contained many missing values for these variables before 1989. However, the two-period lag implies that both variables are fully pre-sample. Note that it is important to instrument for population in our analysis, as current population also appears as the denominator of the dependent variable. Unfortunately, we could not use a lagged instrument for HOTEL because REGIO only reports this variable since 1995 . We then looked for a pre-sample measure that could be correlated with it. REGIO provides a long-time series on airplane passengers embarked and disembarked in the region, which is clearly correlated with the number of people visiting the region, and hence with HOTEL. Since PASS may also be a consequence rather than a cause of regional performance we deliberately picked the longest possible lag that we could construct, which was four periods.

\subsection{Regional Performance: Empirical Results}

Table 3 reports our OLS and two IV regressions, which we label IV(1) and IV(2). In the first three columns we employ HRSTE as a measure of technological capabilities, while in the final three columns we employ KPAT.

\section{TABLE 3 ABOUT HERE}

We performed a Wu-Hausman specification test to assess whether the key parameters of our analysis, i.e., $\alpha_{O P E N}, \alpha_{H O T E L}$, and $\alpha_{H R S T E}$ or $\alpha_{K P A T}$, were jointly 
different in IV(1) with respect to OLS, and in IV(2) with respect to IV(1). The test computes the statistic $\left(\boldsymbol{\alpha}_{1}-\boldsymbol{\alpha}_{\mathbf{0}}\right)^{\prime}\left(\mathbf{V}_{\mathbf{1}}-\mathbf{V}_{\mathbf{0}}\right)^{-1}\left(\boldsymbol{\alpha}_{\mathbf{1}}-\boldsymbol{\alpha}_{\mathbf{0}}\right)$ where $\boldsymbol{\alpha}_{1}-\boldsymbol{\alpha}_{\mathbf{0}}$ is the difference between the estimated parameter vectors under the tested and the efficient specification, i.e., IV(1) and OLS or IV(2) and IV(1) in our case, and $\mathbf{V}_{\mathbf{1}}-\mathbf{V}_{\mathbf{0}}$ is the difference in the variance-covariance matrices of $\boldsymbol{\alpha}_{\mathbf{1}}$ and $\boldsymbol{\alpha}_{\mathbf{0}}$. This statistic is distributed as $\chi^{2}$ with degrees of freedom equal to the number of tested parameters. In the HRSTE specification, the test statistic was 6.46 in the IV(1) vs. the OLS test, which implies rejection of the null hypothesis of equality of the coefficients at $p<10 \%$, and 36.30 in the IV(2) vs. the IV(1) test, which rejects the null hypothesis at $\mathrm{p}<1 \%$. In the KPAT specifications the two statistics were respectively 2.14 , which does not reject the null hypothesis in IV(1) vs. OLS, and 37.67, which rejects the null hypothesis in IV(2) vs. $\operatorname{IV}(1)$ at $\mathrm{p}<1 \%$.

Our estimated elasticity of openness, $\alpha_{O P E N}$, is around 0.25 in the HRSTEregressions, and it drops by about half in the KPAT-regressions. In the HRSTEregressions $\alpha_{O P E N}$ is significant at $\mathrm{p}<1 \%$ or $\mathrm{p}<5 \%$. Similarly, in the KPATregressions it is significant at $\mathrm{p}<1 \%$ in OLS and IV(1), while its p-value is barely higher than $10 \%$ in IV(2). The lower significance of $\alpha_{O P E N}$ in the latter case is not a major concern. The drop in statistical significance is fairly natural given that we use instrumental variables and we do not have a very high number of observations. Moreover, when we tested for the significance of $\alpha_{O P E N}{ }^{*} \alpha_{H O T E L}$ in the IV(2) equation with KPAT, the corresponding p-value was $6.3 \%$, well below $10 \%$. Finally, in the HRSTE-equations the estimated weight $\alpha_{\text {HOTEL }}$ indicates that about three-fourths of the openness index is accounted for by HOTEL and one-fourth by LANG, while in the KPAT-equations the weight of HOTEL increases to basically 1 in the IV(2) equation. Finally, the estimated effects of our index of openness are not small. To provide a sense 
of the orders of magnitude involved, we look at a one standard deviation change in HOTEL centered around the sample average of this variable, when all else is held constant. From Table 2 this relative change is $\frac{\triangle H O T E L}{H O T E L}=\frac{1.049}{0.659}=1.592$. Given the estimated parameters of IV(2) with KPAT in Table 3, the corresponding relative increase in income $\frac{\Delta Y}{Y}$ is $0.151 * 0.997 * 1.592=0.240$, i.e. about one-fourth of the relative change in HOTEL. Note from Table 2 that a one standard deviation increase in income centered around its sample mean is $9.954 / 36.641=0.272$. The relative one standard deviation change in HOTEL then produces an estimated relative change in income (0.240) slightly smaller than the equivalent relative one standard deviation increase in income in our sample (0.272).

Our estimated elasticities of openness are smaller than both Frankel and Romer (1999) and Alcalà and Ciccone (2004). Frankel and Romer's IV elasticity of tradeopenness is about 2, while in Alcalà and Ciccone it is slightly higher than 1 . An obvious reason for this difference is that they measure the impact of trade-openness while we use a different measure of openness. Moreover, we look at the impact of openness on regional performance as opposed to countries. Thus, comparing the magnitudes of the impacts of openness between our study and the country studies is not meaningful. More important is the fact that, in spite of our different settings (regions vs. countries), samples (European regions vs. countries worldwide), and measures of openness (trade vs. a broader measure of openness), we also find a positive and significant impact of openness on performance after controlling for its endogeneity.

We confirm previous results in the literature on the impact of technology and agglomeration on regional performance. First, HRSTE has a sizable and significant impact, and so does KPAT in the second set of equations. This is consistent with 
previous work on the role of research, technology and innovation in producing differences across European regions. Among the others, our finding mirrors the results by Fagerberg et al. (1997) and Paci and Usai (2000) on the positive relation between R\&D or technological capabilities and regional performance in Europe. Second, we find that population density also has a positive and significant impact on regional performance. Thus, our results confirm the two classical explanations of regional advantage - technology and agglomeration economies. Our contribution is that openness also matters, even after controlling for technology and agglomeration.

The negative and significant effect of population accounts for diminishing returns. The variable MTW does not seem to have an important effect. The effect of motorway infrastructures is probably captured by some of the other covariates. The impact of TOURISM is negative and fairly well measured. As discussed earlier, this variable was included to control for the possibility that our measure of openness captures the impact of the tourist intensity of the region. Since tourist regions are typically also less wealthy, the negative sign of TOURISM was expected. As noted earlier, we also tried other variables in the regressions and none of them were statistically significant.

\section{DIRECT AND INDIRECT EFFECTS OF OPENNESS}

\subsection{Specification and results}

The drop in the elasticity of openness when we use KPAT instead of HRSTE suggests that KPAT captures part of the effects of openness. Patents are a measure of output, and therefore they are functions of technological inputs like HRSTE or openness. Since knowledge is fertilized by other knowledge and ideas, openness may contribute to innovation output by providing access to a wider set of knowledge sources. Thus, openness may have a direct effect on productivity and an indirect one through patents.

To test for the presence of these effects, we jointly estimate two equations. The 
first one is our equation for regional performance (1) with KPAT as the TECH regressor. The second equation explains KPAT as a function of the same covariates in (1) with HRSTE in lieu of TECH, viz.

$$
\begin{aligned}
\log \left(\text { KPAT }_{i t}\right)= & \text { constant }+ \text { country dummies }+ \text { time dummy }+ \\
& \beta_{\text {OPEN }} \cdot\left[\beta_{H O T E L} \cdot \log \left(H O T E L_{i t}\right)+\left(1-\beta_{H O T E L}\right) \cdot \log \left(L_{A N G_{i t}}\right)\right]+ \\
& \beta_{T E C H} \cdot \log \left(H R S T E_{i t}\right)+\beta_{D E N S} \cdot \log \left(D E N S_{i t}\right)+ \\
& \beta_{P O P \cdot} \cdot \log \left(P O P_{i t}\right)+\text { controls }+\mu_{i t}
\end{aligned}
$$

where the $\beta$ are parameters to be estimated, $\mu_{i t}$ is the error-term, and HRSTE is an input for the production of patents. In this two-equation estimation we employ the same instruments used in our single-equation estimation. ${ }^{4}$

Note that in (2) we allow for a different index of openness than in the regional performance equation, as we let the weights be different than in (1). In principle, if the expression in the square brackets is a measure of openness it should be the same in both equations as it represents the same type of variable. In this case, $\beta_{O P E N}$ and $\alpha_{O P E N}$ in equation (1) would account for its different impact in the two equations. However, there are reasons suggesting that we should differentiate the weights in the two equations. From a purely empirical point of view, different weights imply a more general specification. At the same time, since our index of openness is a proxy for an underlying concept, a more flexible specification can capture potentially different components of this covariate. For the same reason, different components of our index may have different importance in different specifications, and we can assess which aspect of openness affects regional performance vs. regional technological capabilities.

The results of our joint estimation of (1) and (2) are in Table 4. The estimated parameters in the regional performance equation are similar to those in Table 3 . In addition, our index of openness has a sizable and significant impact on KPAT. This 
confirms that openness has both a direct and an indirect effect on regional performance. Moreover, in the IV regressions the estimated weight of LANG in the KPAT equation is higher than in the performance equation. This is because in the kind of openness that matters for acquiring knowledge capabilities - like tapping into wider, typically international, scientific and technological networks - linguistic skills are relatively more important. Thus, we can only expect them to weigh less in the direct effect of openness, which is mostly associated with non-technological factors. We also find a sizable and significant impact of HRSTE on KPAT. This reinforces our conjecture that HRSTE is an input to KPAT which then affects regional performance. Density is still important as a direct effect to regional performance, but in the IV regressions it is not as important as an effect on the accumulation of technological capabilities.

\section{TABLE 4 ABOUT HERE}

The indirect effect of openness is sizable. We can perform the same exercise that we performed earlier and look at a one standard deviation in HOTEL and LANG centered around their sample means. This is 1.592 in the case of HOTEL, as computed earlier, and $0.213 / 0.469=0.454$ in the case of LANG. Consider the change in HOTEL first. Given the estimated parameters in the IV(2) regression in Table 4, the estimated direct effect of openness on income is the same as earlier, i.e. $0.151 * 0.997 * 1.592=$ 0.240. To obtain the indirect effect we first compute the impact of a one standard deviation increase in HOTEL on KPAT. This is $0.905 * 0.539 * 1.592=0.776$. The indirect impact on income through KPAT is then $0.156^{*} 0.776=0.121$, or about $50 \%$ of the direct effect. The total (direct plus indirect) impact is 0.361 . Since the relative one standard deviation increase in income centered around its sample mean is 0.272 , as computed earlier, the total impact corresponds to an increase that is almost one-third higher than the relative one standard deviation increase in income in our sample. If we add a relative one standard deviation increase in LANG centered around its mean, 0.454 
computed above, the direct effect is unaffected because the impact of LANG on income in IV(2) is practically zero. The indirect effect is $0.156 * 0.905 * 0.461 * 0.454=0.030$. Thus, the total change in relative income following the one standard deviation increases on the sample means in both HOTEL and LANG is 0.391, which is well above the change in income by one standard deviation on the sample mean in our sample.

To summarize, our index of openness has a sizable effect on regional per capita income as a proxy for regional labor productivity. First, there is an important direct effect. Openness embeds regions in wider networks and this affects its performance in various ways. The direct effect can take various forms. For example, open regions exhibit greater links with the national or international markets. Therefore, they can capture earlier - and more effectively - shocks to demand. As discussed in Section 2, a good deal of the growth of the Indian, Irish, or Israeli IT industries stemmed from their ability to take advantage, more than other emerging regions, of the growth in the demand for IT by the advanced economies. In turn, this stemmed from their established linkages with such markets in the form of familiarity with the English language, a good deal of expatriates to the US, and especially in the case of Ireland, and partly Israel, the presence of multinational enterprises in the country. As also discussed in Section 2 this may have taken the form of greater exports. However, the direct effect can also take subtler forms, like exposure to international best practices, feedbacks from advanced users, links to better suppliers or access to learning processes.

In addition, we find that there is an important indirect effect of openness. Openness affects the innovation output of the regions, which then affects their performance. Interestingly, an increase in the linguistic skills of the population has a smaller overall effect than an increase in HOTEL. However, the indirect effect of LANG on regional performance is much higher than its direct effect. This indicates that the language skills of the population are more important for accumulating technological 
capabilities than for their direct effect on regional performance. This is suggestive of the nature of the links between openness, technology, and performance. Knowledge of languages most likely accounts for the ability to access a wider pool of knowledge assets. Since knowledge is typically produced more efficiently when one has access to wider and better knowledge inputs, our results emphasize the importance of being hooked into wide international networks for both the production of technology and regional economic performance.

\subsection{Robustness checks}

We provide three robustness checks of our results. They are shown in Table 5.

\section{TABLE 5 ABOUT HERE}

We first run our IV(2) regression by employing the English equivalent of LANG (i.e., by considering only people who speak English rather than any other language) and after removing the UK regions. Our empirical results are robust to this specification. Interestingly, we now find that the direct impact of openness $\left(\alpha_{O P E N}\right)$ is smaller, while the indirect impact of openness $\left(\beta_{O P E N}\right)$ is higher. Moreover, we find that the impact of LANG is higher especially in the KPAT equation. This suggests that the use of English as a proxy for openness reinforces our interpretation of the results, viz. the knowledge of English means that the regions are more embedded into international knowledge networks, and this strengthens the indirect effect of openness and the role of language and communication in affecting it.

Our second check hinges on the fact that globalization has grown steadily throughout the 1990s. We then expect that the impact of openness on performance will be higher in our second period compared to the first one. In addition, the growing importance of services and less tangible goods suggests that the more intangible components of openness, which we summarized by language skills in the region, have 
become more important. At the same time, not only has scientific and technological knowledge grown worldwide during the 1990s, but more countries and regions in the world have become relevant producers of knowledge, technologies, and innovation. As a result, an open region has more opportunities to tap into external knowledge inputs. We then also expect the impact of our index of openness on KPAT to be higher in the second period.

Table 5 presents the results of a joint estimation of (1) and (2) for each of our two periods. Both equations use the same regressors and instruments (appropriately lagged) of the panel estimation. The regional performance equation shows that in 1995-1997 the direct impact of openness, $\alpha_{O P E N}$, is less than one third of the impact of openness in 1998-2000. Moreover, $\alpha_{\text {HOTEL }}$ is smaller in the latter period. As predicted, the direct impact of openness has become more important in the second period, and the relevance of communication and more intangible components of the openness index has also increased. Likewise, the impact of openness on KPAT, $\beta_{O P E N}$, has increased in the second period, and $\beta_{\text {HOTEL }}$ has decreased. The statistical significance of these coefficients is less sizable than in the panel estimation because of the lower number of observations in each equation. However, the point estimates are in the direction that we are suggesting.

In our third robustness check we run our two equations by replacing $\log \left(Y_{i t}\right)$ and $\log \left(K P A T_{i t}\right)$ with their differences from their region average across the two periods. Because of the very large number of regions compared to only two time periods we could not estimate our equations with regional fixed effects. This is the closest attempt to control for regional individual effects. Also, since for a few regions we only had observations in one period, the corresponding net variable was zero. We preferred to include these observations in our equations to keep the same number of observations as 
in the previous equations. When we eliminated them the results did not change. The results of this estimation are similar to those in Table 4.

\section{CONCLUSIONS}

This paper contributes to the tradition of studies on the economic performance of regions, and particularly of European region (e.g., Fagerberg et al., 1997; Verspagen, 1997; Caniels, 1999; Paci and Usai, 2000). Its empirical results corroborate the key findings of this literature, particularly that $\mathrm{R} \& \mathrm{D}$, patents, or more generally technological capabilities have a sizable and significant effect on regional economic performance in Europe. In addition, we find evidence of agglomeration economies consistent with the tradition of studies on this matter (e.g. Audretsch and Feldman, 1996; Porter, 1998; Swann et al. 1999; Ciccone, 2002; Döring and Schnellenbach, 2006). Specifically, we find a positive and significant effect of population density on our measure of regional productivity.

The main contribution of this paper is to link this literature to the growing literature on the importance of "openness" for economic performance. We find that, along with technology and agglomeration, among European regions openness also matters. Moreover, we were careful in trying to pick the effects of openness on performance and not the other way around, or some spurious correlations.

This has natural policy implications. Particularly, actions aimed at making a region less "provincial" can be quite important. As a first step in this kind of study, we did not distinguish whether openness is produced by spillovers due to mobile and internationalized human capital, the presence of multinational corporations, or other factors. These can be topics for future and more focused research, which require new data collections. However, the experience of some of the fast growing regions of the world today (e.g., the Asian Tigers, Ireland, or Israel) indicates that these factors are 
correlated with one another. In short, there may be underlying factors that account for the extent to which some regions are more open than others, and we found that these factors matter.

\section{References}

ALCALA' F. and CICCONE A. (2004) Trade and Productivity, Quarterly Journal of Economics, 119 (2), 613-646.

ARORA A. and GAMBARDELLA A. (Eds.) (2005) From Underdogs to Tigers: The Rise and Growth of the Software Industry in Brazil, China, India, Ireland, and Israel, Oxford University Press, Oxford UK.

ARORA A., GAMBARDELLA A. and TORRISI S. (2004) In the Footsteps of the Silicon Valley? Indian and Irish Software in the International Division of Labor, in BRESNAHAN T. and GAMBARDELLA A. (Eds.) Building High-Tech Clusters: Silicon Valley and Beyond, Cambridge University Press, Cambridge UK.

AUDRETSCH D.B. and FELDMAN M.P. (1996) Knowledge Spillovers and the Geography of Innovation and Production, American Economic Review, 86 (3), 630640.

BRESNAHAN T. and GAMBARDELLA A. (2004) (Eds.) Building High-Tech Clusters: Silicon Valley and Beyond, Cambridge University Press, Cambridge UK.

Business Week (2001) The Great English Divide, August 13, 36-40, European Edition. CANIELS M. (1999) Regional Growth Differentials. The Impact of Locally Bounded Knowledge Spillovers, $\mathrm{PhD}$ dissertation, University of Maastricht.

CICCONE A. (2002) Agglomeration Effects in Europe, European Economic Review, $46,213-227$. 


\section{COMMISSION OF THE EUROPEAN COMMUNITIES (CEC) (2007)}

Communication of the Commission: Fourth Report on Economic and Social Cohesion, COM (2007) 273.

DÖRING T. and SCHNELLENBACH J. (2006) What Do We Know About Geographical Knowledge Spillovers and Regional Growth? A Survey of the Literature, Regional Studies, 40 (3), 375-95.

FAGERBERG, J., VERSPAGEN, B. AND CANIELS, M. (1997) Technology, Growth and Unemployment across European Regions, Regional Studies, 31 (5), 457-466.

FRANKEL J. and ROMER P. (1999) Does Trade Cause Growth?, American Economic Review, 89 (3), 379-99.

MINISTERO DELL'INDUSTRIA (2000), Nono rapporto sul Turismo Italiano 2000, Ministero dell'Industria, Rome.

PACI R. and USAI S. (2000) Technological Enclaves and Industrial Districts: An Analysis of the Regional Distribution of Innovative Activity in Europe, Regional Studies, 34 (2), 97-114.

PORTER M. E. (1998) Clusters and the New Economics of Competition, Harvard Business Review, Nov-Dec, 77-90.

PUGA D. (1999) The Rise and Fall of Regional Inequalities, European Economic Review 43, 303-334.

SAXENIAN A. (1994) Regional Advantage. Culture and Competition in Silicon Valley and Route 128, Harvard University Press, Cambridge (MA).

SHANG-JIN W. and YI W. (2001) Globalization and Inequality: Evidence from Within China, NBER Working Paper 8611.

SWANN P., PREVEZER M. and STOUT D. (Eds.) (1998) The Dynamics of Industrial Clustering. International Comparisons in Computing and Biotechnology, Oxford University Press, Oxford UK. 
VERSPAGEN B. (1997) European Regional Clubs: Do They Exist and Where Are They Heading? On Economic and Technological Differences between European Regions, in ADAMS J. and PIGLIARU F. (Eds.) Economic Growth and Change: National and Regional Patterns of Convergence and Divergence, Edward Elgar, Cheltenham.

Acknowledgements: We thank Zoltan Acs, Suma Athreye, Andrea Bassanini, Swayan Chaudhuri, Antonio Ciccone, Simona Iammarino, Hugo Hollanders, Steve Klepper, Franco Malerba, Xavier Martin, Alessandro Nuvolari, David Soskice, Davide Ticchi, James Wade, Filippo Carlo Wezel, and two anonymous referees for helpful comments and suggestions. All responsibilities are ours. We acknowledge financial support from the European Commission DG Research, the CNR-ESF Projects "Science and Technology in Large and Small Firms", and Bocconi University. 


\section{TABLES}

Table 1. List of variables

\begin{tabular}{|c|c|}
\hline$Y_{i t}$ & $\begin{array}{l}\text { Regional GDP (in PPP and corrected for inflation) over population 25-65 [in } \\
000 \text { euros] }\end{array}$ \\
\hline HOTEL $_{i t}$ & Share of hotels on the population (in 000) of the region \\
\hline$L A N G_{i t}$ & $\begin{array}{l}\text { Share of individuals in the Eurobarometer sample who live in the region, are } \\
27 \text { or more at the beginning of the two periods, and know a foreign } \\
\text { language. Proxies for the share of regional population who knows a foreign } \\
\text { language (Source: Special Survey on Languages, Eurobarometer 54) }\end{array}$ \\
\hline$H R S T E_{i t}$ & $\begin{array}{l}\text { Human Resources in Science and Technology - people who have } \\
\text { successfully completed third level education [in 000] }\end{array}$ \\
\hline$K P A T_{i t}$ & $\begin{array}{l}\text { Stock of European patent applications computed from the number of annual } \\
\text { patent applications in region } i \text { using a } 0.25 \text { depreciation rate. Initial value of } \\
\text { stock for } 1989\left(1^{\text {st }} \text { year of patent application data in REGIO) obtained as }\right. \\
\text { ratio between the number of patent applications in the region and the } \\
\text { depreciation rate } 0.25\end{array}$ \\
\hline$D E N S_{i t}$ & Population density = Population $\left[\right.$ in 000] $/$ Area $\left[\right.$ in $\left.\mathrm{Km}^{2}\right]$ \\
\hline$P O P_{i t}$ & Population [in 000] \\
\hline$M T W_{i t}$ & Motorways length [in Km] \\
\hline TOURISM & $\begin{array}{l}\text { Share of annual arrivals of non-residents in the region who are } \\
\text { accommodated in establishments other than hotels, e.g. campings or hostels }\end{array}$ \\
\hline $\begin{array}{l}\text { Country } \\
\text { dummies }\end{array}$ & $\begin{array}{l}\text { Dummies for European country of the region: AT, BE, DE, ES, GR, FR, IT, } \\
\text { NL, PT, UK. Default dummy groups Denmark and regions from Finland, } \\
\text { Ireland, and Sweden, which had too few regions to make separate country } \\
\text { dummies. }\end{array}$ \\
\hline
\end{tabular}

Time dummy Dummy equal to 1 for 1998-2000 and zero otherwise

\section{Additional variables used as instruments}

LANG18 ${ }_{i t} \quad$ Like LANG, but only individuals who learned the second language before they were 18 (Source: Special Survey on Languages, Eurobarometer 54)

UNILAB95 $\quad$ Number of university research laboratories in the region in 1995 (Source: European R\&D database, Reed Elsevier Publisher, 1996)

PASS $_{i t-4} \quad$ Number of airplane passengers embarked and disembarked in the region lagged four periods (1986-1988 for 1998-2000 and 1983-1985 for 19951997 [in 000]

POP $\quad$ Population lagged two periods (1992-1994 for 1998-2000 and 1989-1991 for 1995-1997) [in 000]

$A R E A_{i} \quad$ Area of region $\left[\right.$ in $\mathrm{Km}^{2}$ ]

$M T W_{i t-2} \quad$ Motorways length lagged two periods (1992-1994 for 1998-2000 and 19891991 for 1995-1997) [in Km]

$i=$ regions, $t=$ two periods, 1995-1997 or 1998-2000. Annual variables averaged over the three years in the period. Sources of data is Eurostat REGIO, unless otherwise indicated. 
Table 2. Descriptive Statistics

\begin{tabular}{|c|c|c|c|c|c|}
\hline Variable & Mean & $\begin{array}{l}\text { Standard } \\
\text { Deviation }\end{array}$ & Minimum & Maximum & $\begin{array}{c}\text { Number of } \\
\text { observations }\end{array}$ \\
\hline$Y_{i t}$ & 36.641 & 9.954 & 18.131 & 88.278 & 248 \\
\hline HOTEL $_{i t}$ & 0.659 & 1.049 & 0.049 & 8.819 & 248 \\
\hline$L A N G_{i t}$ & 0.469 & 0.213 & 0.100 & 1 & 248 \\
\hline$H R S T E_{i t}$ & 300.374 & 299.790 & 8.878 & 2312.540 & 248 \\
\hline$K P A T_{i t}$ & 1050.594 & 1581.912 & 1.251 & 10718.990 & 248 \\
\hline$D E N S_{i t}$ & 0.348 & 0.753 & 0.003 & 5.921 & 248 \\
\hline$P O P_{i t}$ & 2579.451 & 2188.926 & 245.233 & 11020.200 & 248 \\
\hline$M T W_{i t}$ & 342.163 & 347.791 & 0 & 2719.333 & 248 \\
\hline TOURISM & 0.276 & 0.168 & 0.001 & 0.857 & 248 \\
\hline$A T_{i}$ & 0.036 & 0.187 & 0 & 1 & 248 \\
\hline$B E_{i}$ & 0.048 & 0.215 & 0 & 1 & 248 \\
\hline$D E_{i}$ & 0.310 & 0.464 & 0 & 1 & 248 \\
\hline$E S_{i}$ & 0.137 & 0.345 & 0 & 1 & 248 \\
\hline$F R_{i}$ & 0.065 & 0.246 & 0 & 1 & 248 \\
\hline$G R_{i}$ & 0.048 & 0.215 & 0 & 1 & 248 \\
\hline$I T_{i}$ & 0.145 & 0.353 & 0 & 1 & 248 \\
\hline$N L_{i}$ & 0.048 & 0.215 & 0 & 1 & 248 \\
\hline$P T_{i}$ & 0.020 & 0.141 & 0 & 1 & 248 \\
\hline$U K_{i}$ & 0.077 & 0.267 & 0 & 1 & 248 \\
\hline Other countries & 0.065 & 0.246 & 0 & 1 & 248 \\
\hline$T I M E_{t}$ & 0.560 & 0.497 & 0 & 1 & 248 \\
\hline$L A N G 18_{i t}$ & 0.351 & 0.194 & 0 & 0.955 & 217 \\
\hline UNILABS95 & 31.152 & 46.792 & 1 & 461.000 & 217 \\
\hline$P A S S_{t-4}$ & 2556.446 & 4671.946 & 0 & 30452.199 & 164 \\
\hline$P O P_{i t-2}$ & 2845.112 & 2326.758 & 236.567 & 10867.600 & 164 \\
\hline$A R E A_{i}$ & 24821.251 & 30453.358 & 415 & 154311.906 & 164 \\
\hline$M T W_{i t-2}$ & 323.551 & 307.332 & 0 & 1929.667 & 164 \\
\hline
\end{tabular}


Table 3. Determinants of Regional Performance - Estimation of (1)

\begin{tabular}{|c|c|c|c|c|c|c|}
\hline Parameters & OLS & IV(1) & IV(2) & OLS & IV(1) & IV(2) \\
\hline Const & $\begin{array}{c}4.031^{* * *} \\
(0.231)\end{array}$ & $\begin{array}{c}5.127^{* * *} \\
(0.595)\end{array}$ & $\begin{array}{l}5.071^{* * *} \\
(0.525)\end{array}$ & $\begin{array}{c}4.084^{* * *} \\
(0.173)\end{array}$ & $\begin{array}{l}3.884^{* * *} \\
(0.207)\end{array}$ & $\begin{array}{c}4.063^{* * *} \\
(0.274)\end{array}$ \\
\hline$\alpha_{\mathrm{OPEN}}$ & $\begin{array}{c}0.223^{* * * *} \\
(0.031)\end{array}$ & $\begin{array}{c}0.250^{* * * *} \\
(0.066)\end{array}$ & $\begin{array}{l}0.291^{* *} \\
(0.121)\end{array}$ & $\begin{array}{c}0.143^{* * *} \\
(0.025)\end{array}$ & $\begin{array}{c}0.115^{* * *} \\
(0.034)\end{array}$ & $\begin{array}{c}0.151 \\
(0.093)\end{array}$ \\
\hline$\alpha_{\text {HOтЕL }}$ & $\begin{array}{c}0.649^{* * *} \\
(0.092)\end{array}$ & $\begin{array}{c}0.533^{* * *} \\
(0.152)\end{array}$ & $\begin{array}{c}0.776^{* * *} \\
(0.195)\end{array}$ & $\begin{array}{c}0.545^{* * *} \\
(0.086)\end{array}$ & $\begin{array}{c}0.528^{* * *} \\
(0.195)\end{array}$ & $\begin{array}{c}0.997^{* * *} \\
(0.277)\end{array}$ \\
\hline$\alpha_{\mathrm{LANG}}$ & $\begin{array}{c}0.351^{* * * *} \\
(0.092)\end{array}$ & $\begin{array}{c}0.467^{* * *} \\
(0.152)\end{array}$ & $\begin{array}{c}0.224 \\
(0.195)\end{array}$ & $\begin{array}{c}0.455^{* * *} \\
(0.086)\end{array}$ & $\begin{array}{c}0.472 \\
(0.195)\end{array}$ & $\begin{array}{c}0.003 \\
(0.277)\end{array}$ \\
\hline$\alpha_{\text {HRSTE }}$ & $\begin{array}{c}0.041 \\
(0.057)\end{array}$ & $\begin{array}{l}0.791^{* * *} \\
(0.304)\end{array}$ & $\begin{array}{l}0.579^{* *} \\
(0.283)\end{array}$ & -- & -- & -- \\
\hline$\alpha_{\mathrm{KPAT}}$ & -- & -- & -- & $\begin{array}{c}0.153^{* * *} \\
(0.011)\end{array}$ & $\begin{array}{c}0.173^{* * *} \\
(0.030)\end{array}$ & $\begin{array}{l}0.156^{* * * *} \\
(0.042)\end{array}$ \\
\hline$\alpha_{\text {DENS }}$ & $\begin{array}{c}0.144^{* * *} \\
(0.019)\end{array}$ & $\begin{array}{c}0.067^{*} \\
(0.034)\end{array}$ & $\begin{array}{c}0.082 \\
(0.061)\end{array}$ & $\begin{array}{c}0.089^{* * *} \\
(0.019)\end{array}$ & $\begin{array}{c}0.062^{* * *} \\
(0.019)\end{array}$ & $\begin{array}{l}0.069^{*} \\
(0.037)\end{array}$ \\
\hline$\alpha_{\mathrm{POP}}$ & $\begin{array}{l}-0.040 \\
(0.065)\end{array}$ & $\begin{array}{l}-0.808^{* *} \\
(0.315)\end{array}$ & $\begin{array}{l}-0.581^{*} \\
(0.321)\end{array}$ & $\begin{array}{c}-0.176^{* * *} \\
(0.020)\end{array}$ & $\begin{array}{c}-0.174^{* * *} \\
(0.040)\end{array}$ & $\begin{array}{l}-0.125^{* *} \\
(0.058)\end{array}$ \\
\hline$\alpha_{\text {MTW }}$ & $\begin{array}{c}0.002 \\
(0.013)\end{array}$ & $\begin{array}{c}0.007 \\
(0.019)\end{array}$ & $\begin{array}{c}-0.004 \\
(0.029)\end{array}$ & $\begin{array}{l}-0.022^{*} \\
(0.012)\end{array}$ & $\begin{array}{c}-0.029^{* *} \\
(0.013)\end{array}$ & $\begin{array}{l}-0.032 \\
(0.020)\end{array}$ \\
\hline$\alpha_{\text {TOURISM }}$ & $\begin{array}{c}-0.040^{* *} \\
(0.017)\end{array}$ & $\begin{array}{l}-0.009 \\
(0.026)\end{array}$ & $\begin{array}{l}-0.023 \\
(0.019)\end{array}$ & $\begin{array}{c}-0.039^{* * *} \\
(0.012)\end{array}$ & $\begin{array}{c}-0.042^{* * *} \\
(0.011)\end{array}$ & $\begin{array}{c}-0.042^{\text {** }} \\
(0.017)\end{array}$ \\
\hline N. of obs. & 248 & 217 & 164 & 248 & 217 & 164 \\
\hline
\end{tabular}

${ }^{* * *} \mathrm{p}<0.01,{ }^{* *} \mathrm{p}<0.05,{ }^{*} \mathrm{p}<0.10$. Heteroskedastic consistent Standard Errors in parenthesis. All regressions include country dummies and the time dummy. IV(I) uses all covariates as instruments, but $\log \left(L A N G_{i t}\right)$ and $\log \left(H_{R S T E_{i t}}\right)$ or $\log \left(K P A T_{i t}\right)$, and it replaces them by $\log \left(U N I L A B 95_{i}\right)$ and $\log \left(L A N G 18_{i t}\right)$. IV (II) also excludes $\log \left(H O T E L_{i t}\right), \log \left(P O P_{i t}\right), \log \left(M T W_{i t}\right)$, and replaces them by $\log \left(P_{A S S_{i t-4}}\right), \log \left(P O P_{i t-2}\right), \log \left(M T W_{i t-2}\right)$. 
Table 4. Determinants of Regional Performance \& Technological Capabilities Joint-estimation of (1) and (2)

\begin{tabular}{|c|c|c|c|}
\hline Parameters & SUR & IV(1) & $\mathbf{I V}(2)$ \\
\hline \multicolumn{4}{|c|}{$\log \left(Y_{i t}\right)$ equation } \\
\hline Const & $\begin{array}{l}4.024^{* * * *} \\
(0.175)\end{array}$ & $\begin{array}{l}3.884^{* * * *} \\
(0.207)\end{array}$ & $\begin{array}{c}4.063^{\text {**** }} \\
0.274\end{array}$ \\
\hline$\alpha_{\text {OPEN }}$ & $\begin{array}{l}0.178^{* * * *} \\
(0.027)\end{array}$ & $\begin{array}{l}0.115^{* * *} \\
(0.034)\end{array}$ & $\begin{array}{l}0.151 \\
0.093\end{array}$ \\
\hline$\alpha_{\text {HOTEL }}$ & $\begin{array}{l}0.603^{* * * *} \\
(0.085)\end{array}$ & $\begin{array}{l}0.528^{* * * *} \\
(0.195)\end{array}$ & $\begin{array}{c}0.997^{* * *} \\
0.277\end{array}$ \\
\hline$\alpha_{\mathrm{LANG}}$ & $\begin{array}{l}0.397^{* * * *} \\
(0.085)\end{array}$ & $\begin{array}{l}0.472^{* *} \\
(0.195)\end{array}$ & $\begin{array}{c}0.003 \\
(0.277)\end{array}$ \\
\hline$\alpha_{\mathrm{KPAT}}$ & $\begin{array}{l}0.085^{* * * *} \\
(0.011)\end{array}$ & $\begin{array}{l}0.173^{* * *} \\
(0.030)\end{array}$ & $\begin{array}{c}0.156^{* * *} \\
0.042\end{array}$ \\
\hline$\alpha_{\text {DENS }}$ & $\begin{array}{l}0.114^{* * * *} \\
(0.018)\end{array}$ & $\begin{array}{l}0.062^{* * * *} \\
(0.019)\end{array}$ & $\begin{array}{l}0.069^{*} \\
0.037\end{array}$ \\
\hline$\alpha_{\mathrm{POP}}$ & $\begin{array}{c}-0.096^{* * *} \\
(0.021)\end{array}$ & $\begin{array}{l}-0.174^{* * * *} \\
(0.040)\end{array}$ & $\begin{array}{c}-0.125^{* * *} \\
0.058)\end{array}$ \\
\hline$\alpha_{\mathrm{MTW}}$ & $\begin{array}{l}-0.012 \\
(0.012)\end{array}$ & $\begin{array}{c}-0.029^{* *} \\
(0.013)\end{array}$ & $\begin{array}{l}-0.032 \\
0.020)\end{array}$ \\
\hline$\alpha_{\text {TOURISM }}$ & $\begin{array}{c}-0.040^{* * * *} \\
(0.013)\end{array}$ & $\begin{array}{c}-0.042^{* * *} \\
(0.011)\end{array}$ & $\begin{array}{c}-0.042^{* *} \\
0.017)\end{array}$ \\
\hline \multicolumn{4}{|c|}{$\log \left(K P A T_{i t}\right)$ equation } \\
\hline Const & $\begin{array}{c}0.103 \\
(0.947)\end{array}$ & $\begin{array}{l}7.207^{* *} \\
(2.828)\end{array}$ & $\begin{array}{l}6.481^{* * * *} \\
(1.960)\end{array}$ \\
\hline$\beta_{\mathrm{OPEN}}$ & $\begin{array}{l}0.526^{* * * *} \\
(0.131)\end{array}$ & $\begin{array}{l}0.783^{* *} \\
(0.318)\end{array}$ & $\begin{array}{l}0.905^{*} \\
(0.468)\end{array}$ \\
\hline$\beta_{\text {HOTEL }}$ & $\begin{array}{l}0.833^{* * * *} \\
(0.177)\end{array}$ & $\begin{array}{l}0.537^{* * *} \\
(0.219)\end{array}$ & $\begin{array}{l}0.539^{* *} \\
(0.274)\end{array}$ \\
\hline$\beta_{\text {LANG }}$ & $\begin{array}{c}0.167 \\
(0.177)\end{array}$ & $\begin{array}{l}0.463^{* *} \\
(0.219)\end{array}$ & $\begin{array}{l}0.461^{*} \\
(0.274)\end{array}$ \\
\hline$\beta_{\text {HRSTE }}$ & $\begin{array}{l}0.491^{* *} \\
(0.234)\end{array}$ & $\begin{array}{l}4.586^{* * *} \\
(1.452)\end{array}$ & $\begin{array}{l}3.723^{* * * *} \\
(1.148)\end{array}$ \\
\hline$\beta_{\text {DENS }}$ & $\begin{array}{l}0.349^{* * * *} \\
(0.071)\end{array}$ & $\begin{array}{c}0.030 \\
(0.155)\end{array}$ & $\begin{array}{c}0.081 \\
(0.233)\end{array}$ \\
\hline$\beta_{\mathrm{POP}}$ & $\begin{array}{l}0.653^{* *} \\
(0.271)\end{array}$ & $\begin{array}{l}-3.673^{* *} \\
(1.499)\end{array}$ & $\begin{array}{l}-2.936^{* *} \\
(1.290)\end{array}$ \\
\hline$\beta_{\mathrm{MTW}}$ & $\begin{array}{l}0.162^{* * * *} \\
(0.044)\end{array}$ & $\begin{array}{l}0.208^{* *} \\
(0.087)\end{array}$ & $\begin{array}{l}0.184^{*} \\
(0.110)\end{array}$ \\
\hline$\beta_{\text {TOURISM }}$ & $\begin{array}{c}0.007 \\
(0.068) \\
\end{array}$ & $\begin{array}{c}0.193 \\
(0.142) \\
\end{array}$ & $\begin{array}{c}0.120 \\
(0.081) \\
\end{array}$ \\
\hline N. of obs. & 248 & 217 & 164 \\
\hline
\end{tabular}

${ }^{* * * *} \mathrm{p}<0.01,{ }^{* *} \mathrm{p}<0.05,{ }^{*} \mathrm{p}<0.10$. Heteroskedastic consistent Standard Errors in parenthesis. Instruments, see Table 3 . 
Table 5. Determinants of Regional Performance \& Technological Capabilities - IV jointestimation of (1) and (2): 1) only non-UK regions and English as foreign language; 2) by period; 3) after removing fixed regional effects

\begin{tabular}{|c|c|c|c|c|}
\hline \multirow{2}{*}{ Parameters } & \multirow{2}{*}{$\begin{array}{l}\text { IV }(2) \\
\text { Only non-UK regions, } \\
\text { English as LANG }(\S)\end{array}$} & \multicolumn{2}{|c|}{$\mathbf{I V}(2)(\wedge)$} & \multirow{2}{*}{$\begin{array}{l}\text { IV }(2) \\
\text { Dep. Var. net of fixed } \\
\text { regional effects }(+)\end{array}$} \\
\hline & & 1995-1997 & 1998-2000 & \\
\hline \multicolumn{5}{|c|}{$\log \left(Y_{i t}\right)$ equation } \\
\hline Const & $\begin{array}{c}3.986^{* * *} \\
(0.290)\end{array}$ & $\begin{array}{c}4.266^{* * * *} \\
(0.953)\end{array}$ & $\begin{array}{c}3.604^{* * * *} \\
(0.376)\end{array}$ & $\begin{array}{l}4.094^{* * *} \\
(0.259)\end{array}$ \\
\hline$\alpha_{\mathrm{OPEN}}$ & $\begin{array}{c}0.122 \\
(0.097)\end{array}$ & $\begin{array}{c}0.091 \\
(0.313)\end{array}$ & $\begin{array}{l}0.298^{* *} \\
(0.146)\end{array}$ & $\begin{array}{c}0.171^{*} \\
(0.089)\end{array}$ \\
\hline$\alpha_{\text {HOTEL }}$ & $\begin{array}{l}0.969^{* *} \\
(0.410)\end{array}$ & $\begin{array}{c}1.278^{*} \\
(0.660)\end{array}$ & $\begin{array}{c}0.688^{* * * *} \\
(0.151)\end{array}$ & $\begin{array}{c}0.951^{* * *} \\
(0.205)\end{array}$ \\
\hline$\alpha_{\text {LANG }}$ & $\begin{array}{c}0.031 \\
(0.410)\end{array}$ & $\begin{array}{l}-0.278 \\
(0.660)\end{array}$ & $\begin{array}{l}0.312^{* * *} \\
(0.151)\end{array}$ & $\begin{array}{c}0.049 \\
(0.205)\end{array}$ \\
\hline$\alpha_{\mathrm{KPAT}}$ & $\begin{array}{c}0.161^{* * *} \\
(0.039)\end{array}$ & $\begin{array}{c}0.161 \\
(0.127)\end{array}$ & $\begin{array}{l}0.155^{* *} \\
(0.064)\end{array}$ & $\begin{array}{c}0.158^{* * *} \\
(0.042)\end{array}$ \\
\hline$\alpha_{\text {DENS }}$ & $\begin{array}{c}0.058^{*} \\
(0.032)\end{array}$ & $\begin{array}{c}0.076 \\
(0.196)\end{array}$ & $\begin{array}{l}0.061^{*} \\
(0.037)\end{array}$ & $\begin{array}{l}0.077^{* *} \\
(0.036)\end{array}$ \\
\hline$\alpha_{\mathrm{POP}}$ & $\begin{array}{c}-0.137^{* *} \\
(0.056)\end{array}$ & $\begin{array}{l}-0.152^{*} \\
(0.227)\end{array}$ & $\begin{array}{l}-0.096 \\
(0.078)\end{array}$ & $\begin{array}{c}-0.122^{* *} \\
(0.058)\end{array}$ \\
\hline$\alpha_{\mathrm{MTW}}$ & $\begin{array}{l}-0.028 \\
(0.021)\end{array}$ & $\begin{array}{l}-0.017 \\
(0.034)\end{array}$ & $\begin{array}{l}-0.051^{*} \\
(0.028)\end{array}$ & $\begin{array}{l}-0.033^{*} \\
(0.019)\end{array}$ \\
\hline$\alpha_{\text {TOURISM }}$ & $\begin{array}{c}-0.044^{* * *} \\
(0.015)\end{array}$ & $\begin{array}{l}-0.022 \\
(0.098)\end{array}$ & $\begin{array}{l}-0.064^{*} \\
(0.037)\end{array}$ & $\begin{array}{c}-0.022 \\
(0.017)\end{array}$ \\
\hline \multicolumn{5}{|c|}{$\log \left(K P A T_{i t}\right)$ equation } \\
\hline Const & $\begin{array}{l}4.753^{* *} \\
(2.083)\end{array}$ & $\begin{array}{c}7.622 \\
(2.894)\end{array}$ & $\begin{array}{l}5.140^{*} \\
(3.010)\end{array}$ & $\begin{array}{l}6.524^{* * *} \\
(1.994)\end{array}$ \\
\hline$\beta_{\text {OPEN }}$ & $\begin{array}{l}1.352^{* * *} \\
(0.511)\end{array}$ & $\begin{array}{c}0.875 \\
(1.712)\end{array}$ & $\begin{array}{c}1.093 \\
(0.753)\end{array}$ & $\begin{array}{c}0.891^{*} \\
(0.471)\end{array}$ \\
\hline$\beta_{\text {НОтеL }}$ & $\begin{array}{l}0.468^{* *} \\
(0.190)\end{array}$ & $\begin{array}{c}0.590 \\
(1.703)\end{array}$ & $\begin{array}{l}0.422^{* *} \\
(0.202)\end{array}$ & $\begin{array}{l}0.564^{* *} \\
(0.276)\end{array}$ \\
\hline$\beta_{\text {LANG }}$ & $\begin{array}{c}0.533^{* * * *} \\
(0.190)\end{array}$ & $\begin{array}{c}0.410 \\
(1.703)\end{array}$ & $\begin{array}{l}0.573^{* * *} \\
(0.202)\end{array}$ & $\begin{array}{c}0.436 \\
(0.276)\end{array}$ \\
\hline$\beta_{\text {HRSTE }}$ & $\begin{array}{c}3.694^{* * *} \\
(1.197)\end{array}$ & $\begin{array}{c}3.957 \\
(4.414)\end{array}$ & $\begin{array}{c}3.692^{* * *} \\
(1.401)\end{array}$ & $\begin{array}{l}3.641^{* * * *} \\
(1.144)\end{array}$ \\
\hline$\beta_{\text {DENS }}$ & $\begin{array}{c}0.033 \\
(0.239)\end{array}$ & $\begin{array}{c}0.057 \\
(1.593)\end{array}$ & $\begin{array}{c}0.114 \\
(0.176)\end{array}$ & $\begin{array}{c}0.083 \\
(0.232)\end{array}$ \\
\hline$\beta_{\mathrm{POP}}$ & $\begin{array}{l}-2.765^{* *} \\
(1.321)\end{array}$ & $\begin{array}{l}-3.239 \\
(5.538)\end{array}$ & $\begin{array}{l}-2.894^{*} \\
(1.503)\end{array}$ & $\begin{array}{c}-2.836^{* *} \\
(1.285)\end{array}$ \\
\hline$\beta_{\text {MTW }}$ & $\begin{array}{c}0.077 \\
(0.119)\end{array}$ & $\begin{array}{c}0.170 \\
(0.382)\end{array}$ & $\begin{array}{c}0.232 \\
(0.145)\end{array}$ & $\begin{array}{c}0.176 \\
(0.107)\end{array}$ \\
\hline$\beta_{\text {TOURISM }}$ & $\begin{array}{c}0.135 \\
(0.085)\end{array}$ & $\begin{array}{c}0.158 \\
(0.645)\end{array}$ & $\begin{array}{c}0.176 \\
(0.223)\end{array}$ & $\begin{array}{c}0.085 \\
(0.080)\end{array}$ \\
\hline N. of obs. & 150 & 77 & 87 & 164 \\
\hline
\end{tabular}

*** $\mathrm{p}<0.01,{ }^{* *} \mathrm{p}<0.05,{ }^{*} \mathrm{p}<0.10$. Heteroskedastic consistent Standard Errors in parenthesis. Instruments, see Table 3. (§) LANG defined as in Table 2 but for people who speak English rather than any other language. All the other variables (including instruments) are unchanged. $\left(^{\wedge}\right)$ Because of few observations, in 1995-1997 we lumped the dummies for BE, NL, PT in the default category. Similarly for AT in 1998-2000. (+) Dependent variables are the OLS residuals of a regression that employs all the regional dummies as covariates. 


\footnotetext{
${ }^{1}$ See however Shang-Jin and Yi (2001).

${ }^{2}$ We could not use employment in the denominator because it had many missing observations in REGIO. We replaced it by population in the workforce age. Since, as we shall see, our regressions are log-log, we can always interpret our estimated parameters as impacts on the region GDP. To be sure, this may also raise the issue that regional GDP is the result of many other influences beyond labor productivity in a narrow sense. Since we do not have very many observations we could not employ a vast array of controls. However, time and country dummies can take care of these factors, especially because most of the controls that we would need are likely to be correlated with one another.

${ }^{3}$ Since Eurobarometer provides the date of birth of the interviewees, we computed the shares of individuals who were 27 or older in 1995 and 1998. However, we cannot take into account the individuals who died. Since LANG and LANG18 are shares, the time period is small, and the largest variation in our data is across regions and not over time, this error is negligible.

${ }^{4}$ We also experimented with the other controls discussed in the previous section, including a measure of capital formation in the region. They turned out to be insignificant in both equations, and they produced no appreciable change in the results.
} 